\title{
THE ACTIONS OF D 600, ASPAMINOL AND PAPAVERINE ON CALCIUM-, POTASSIUM- AND HISTAMINE-INDUCED CONTRACTIONS OF ISOLATED RABBIT BASILAR ARTERY, AORTA, TAENIA COLI AND TRACHEAL SMOOTH MUSCLE
}

\author{
Mitsuo OHASHI and Issei TAKAYANAGI* \\ Department of Chemical Pharmacology. Toho University School of Pharmaceutical Sciences, \\ Funabashi, Chiba 274, Japan
}

Accepted June 4, 1983

\begin{abstract}
The effects of D 600. Aspaminol (1,1-diphenyl-3-piperidinobutanol hydrochloride) and papaverine on $\mathrm{CaCl}_{2}, . \mathrm{KCl}$ - and histamine-induced contractile responses of isolated rabbit basilar artery, aorta, taenia coli and tracheal smooth muscle were compared with each other. D 600 reduced $\mathrm{CaCl}_{2}$-induced maximal responses in basilar artery and aorta, and parallelly shifted the concentration-response curves for $\mathrm{CaCl}_{2}$ to the right in taenia coli and trachea. D 600 also reduced histamine-induced maximal contractions in basilar artery and taenia coli. These reductions were not reversed by increasing $\mathrm{CaCl}_{2}$ concentration in bathing fluids. High concentration of D 600 parallelIy shifted the concentration-response curve for histamine to the right in aorta. Like D 600. Aspaminol, a nonspecific smooth muscle relaxant, parallelly shifted the concentration-response curve for histamine in aorta. Papaverine parallelly shifted the concentration-response curve for $\mathrm{CaCl}_{2}$ in taenia coli and reduced the maximal responses in other tissues. Papaverine also reduced histamine-induced maximal responses in basilar artery. aorta and taenia coli. Influences of these smooth muscle relaxants on histamine-induced contraction in Ca-free buffer solution and on $\mathrm{KCl}$-induced contraction in normal and high $\mathrm{Ca}$ (Ca: $12.5 \mathrm{mM}$ ) buffer solution were also studied. From the results obtained in this study, the effects of smooth muscle relaxants are considered to vary with the type of smooth muscle or the condition eliciting contraction, and the possible mechanisms of the contractions were discussed.
\end{abstract}

It is well known that activation of the contractile mechanism in smooth muscle is triggered by an increase in free $\mathrm{Ca}$ ions in the cytoplasm (1, 2). This contractile mechanism is considered to be achieved either by release of intracellularly sequestered (e.g., sarcoplasmic reticulum, mitochondria, plasma membrane) $\mathrm{Ca}$ or by the increase in influx of extracellular $\mathrm{Ca}(3-5)$. It is believed that all of the smooth muscle relaxants might elicit their actions by decreasing the level of activator $\mathrm{Ca}$ in the cytoplasm. Several

* To whom reprint requests should be adressed. compounds which specifically block slow inward current at the cardiac plasma membrane had been designated as " $\mathrm{Ca}$ antagonists" by Fleckenstein et al. (6). In smooth muscles, these compounds specifically block the influx of $\mathrm{Ca}$ ions through a voltage sensitive Ca channel which is activated by the depolarization of plasma membrane $(7,8)$, and some of these compounds are used clinically in the therapy of various diseases such as hypertension, cardiac ischemia, arrhythmias, disfunction of cerebral circulation and others (9-11). In smooth muscles, the sources of intracellular activator 
Ca or the influx pathway of extracellular $\mathrm{Ca}$ vary with the tissues, contracting agents or conditions. For example, $\mathrm{K}$ ion stimulates the influx of $\mathrm{Ca}$ by activating voltage sensitive Ca channel in most of the smooth muscles (7. 8, 12). Histamine causes the contraction of rabbit taenia coli mainly by increasing influx of extracellular $\mathrm{Ca}$ when compared with acetylcholine $(13,14)$. Acetylcholine, especially in high concentration, and carbachol release intracellularly sequestered $\mathrm{Ca}$ in guinea pig taenia coli and dog tracheal smooth muscle (15-17). In most of the vascular tissues, norepinephrine causes the contraction mainly by releasing $\mathrm{Ca}$ from an intracellular Ca store $(12,18,19)$. Thus, it is also considered that the actions of smooth muscle relaxants vary with the differences of contractile mechanisms among smooth muscle tissues.

In this study, the actions of D 600, a Ca antagonist, on rabbit basilar artery, aorta, taenia coli and tracheal smooth muscle were investigated and were compared with the actions of nonspecific smooth muscle relaxants such as papaverine and Aspaminol.

\section{Materials and Methods}

Helically cut strips of basilar artery and aorta. strip of taenia coli and tracheal chain were prepared from male albino rabbits weighing $2-3 \mathrm{~kg}$. These preparations were suspended in an organ bath containing $20 \mathrm{ml}$ of Krebs buffer solution with following composition $(\mathrm{mM}): \mathrm{NaCl}, 118 ; \mathrm{KCl}, 4.5$; $\mathrm{CaCl}_{2}$, 2.5; $\mathrm{MgSO}_{4}, 1.0 ; \mathrm{KH}_{2} \mathrm{PO}_{4}, 1.0$; $\mathrm{NaHCO}_{3}, 25.0$; glucose, 6.0. Buffer solution was kept at $32 \pm 0.5^{\circ} \mathrm{C}$ and bubbled with a mixture of $95 \% \quad \mathrm{O}_{2}$ and $5 \% \quad \mathrm{CO}_{2}$ in basilar artery and aorta and with air in taenia coli and trachea. Mechanical responses were measured isometrically under $0.25 \mathrm{~g}$ of resting tension in basilar artery and isotonically under $0.5 \mathrm{~g}$ load in aorta, taenia coli and trachea. All of the preparations were allowed to equilibrate for at least $1 \mathrm{hr} . \mathrm{CaCl}_{2}$ induced contractile response was measured in high-K.Ca-free buffer solution of the following composition $(\mathrm{mM})$ : $\mathrm{KCl}, 122.5$; $\mathrm{MgSO}_{4}, 1.0 ; \mathrm{KH}_{2} \mathrm{PO}_{4}, 1.0 ; \mathrm{NaHCO}_{3}, 25.0$; glucose, $6.0 . \mathrm{KCl}$-induced contraction was measured using solutions in which various concentrations of $\mathrm{NaCl}$ were replaced with $\mathrm{KCl}$ isosmotically. In some of the experiments, high $\mathrm{Ca}$ ( $\mathrm{Ca}: 12.5 \mathrm{mM}$ ) buffer solution was used. Smooth muscle relaxants were added $5 \mathrm{~min}$ before the addition of contracting agents. In experiments to determine the actions of smooth muscle relaxants on contractions which are considered to occur by $C$ a released from an intracellular Ca store, tissues were incubated in buffer solution containing $1 \mathrm{mM} \mathrm{Ca}$ for $10 \mathrm{~min}$ in basilar artery, $45 \mathrm{~min}$ in aorta and 20 min in taenia coli, after the tissue Ca was depleted by repeated applications of histamine in Ca-free buffer solution. Thereafter, tissues were washed for $5 \mathrm{~min}$ with Ca-free buffer solution in the absence (control) or presence of smooth muscle relaxants following by the addition of histamine $\left(10^{-4} \mathrm{M}\right)$.

Drugs used: D 600 (methoxyverapamil; Knoll), Aspaminol (1.1-diphenyl-3-piperidinobutanol hydrochloride, Kowa), papaverine hydrochloride (Tokyo Kasei), histamine dihydrochloride (Wako Junyaku). Each value was presented as a mean with standard error. and statistical significance was evaluated by Student's $t$-test.

\section{Results}

Influences of $\mathrm{D}$ 600, Aspaminol and papaverine on $\mathrm{CaCl}_{2}$-induced contractile responses in isolated rabbit basilar artery, aorta, taenia coli and trachea (Fig. 1, Table 1): D 600 inhibited $\mathrm{CaCl}_{2}$-induced contractile responses of basilar artery and aorta in a noncompetitive manner, whereas it parallelly shifted the concentration-response curves for $\mathrm{CaCl}_{2}$ to the right in taenia coli and 
trachea. Aspaminol inhibited $\mathrm{CaCl}_{2}$-induced contractile response of basilar artery in a noncompetitive manner, whereas it parallelly shifted the concentration-response curves for
$\mathrm{CaCl}_{2}$ to the right in other tissues. The inhibitory action of Aspaminol was most potent in trachea. Papaverine inhibited $\mathrm{CaCl}_{2}$ induced contractile responses of basilar

D 600
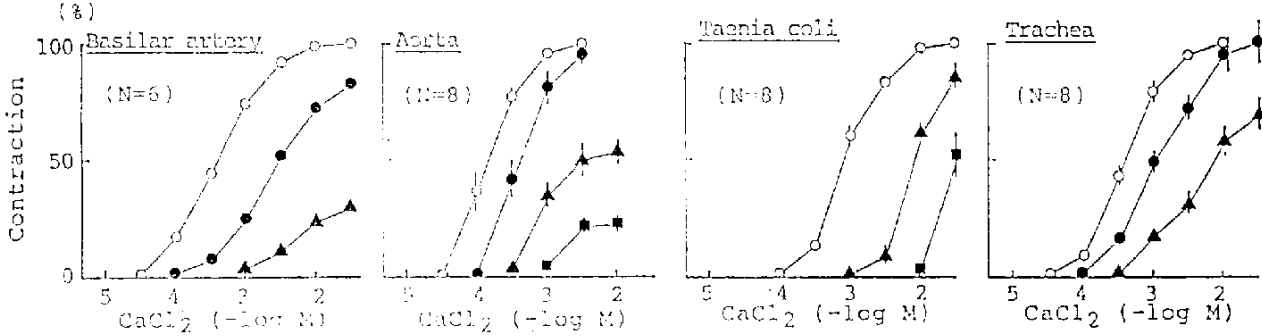

Aspaminol
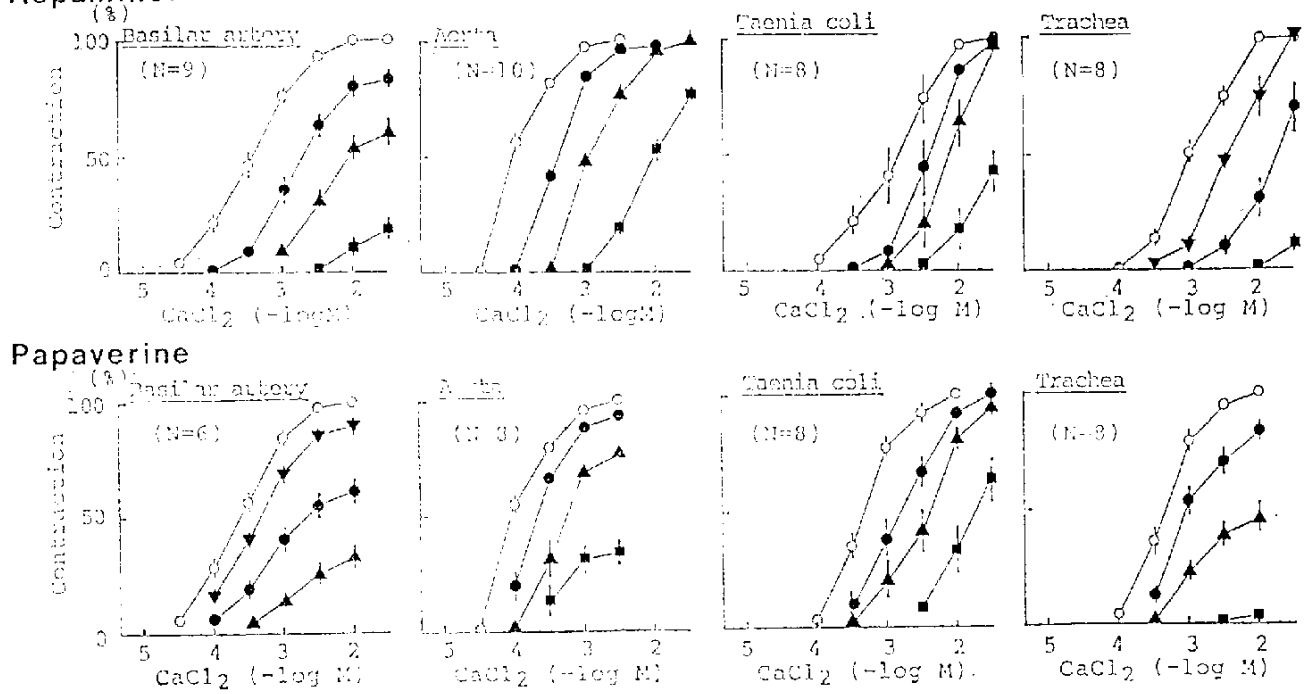

Fig. 1. Concentration-response curves for $\mathrm{CaCl}_{2}$ on isolated rabbit basilar artery, aorta, taenia coli and tracheal smooth muscle in the absence and presence of D 600 (top). Aspaminol (middle) and papaverine (bottom). The concentration of smooth musce relaxants used are indicated by the following symbols. O: control, D $600\left(\mathbf{O}: 10^{-8} \mathrm{M}, \mathbf{\wedge}: 10^{-7} \mathrm{M}, \mathbf{\mathbf { Q }}: 10^{-6} \mathrm{M}\right)$. Aspaminol $\left(\boldsymbol{\nabla}: 3 \times 10^{-6} \mathrm{M}, \boldsymbol{0}: 10^{-5} \mathrm{M}, \mathbf{\Lambda}: 3 \times 10^{-5}\right.$ $\left.\mathrm{M}, \boldsymbol{\square}: 10^{-4} \mathrm{M}\right)$. papaverine $\left(\boldsymbol{\nabla}: 3 \times 10^{-6} \mathrm{M}, \bigcirc: 10^{-5} \mathrm{M}, \mathbf{A}: 3 \times 10^{-5} \mathrm{M}, \boldsymbol{\square}: 10^{-4} \mathrm{M}\right)$. Each point and vertical bar represent the mean value and standard error, respectively. $N$ : Number of experiments.

Table 1. Comparison of the antagonistic actions of $\mathrm{D} 600$. Aspaminol and papaverine on $\mathrm{CaCl}_{2}$-induced contractions of isolated rabbit basilar artery, aorta taenia coli and tracheal smooth muscle

\begin{tabular}{|c|c|c|c|c|c|}
\hline Drugs & & Basilar artery & Aorta & Taenia coli & Trachea \\
\hline D 600 & $\begin{array}{l}\left(\mathrm{pA}_{2}\right) \\
\left(\mathrm{pD}_{2}{ }_{2}\right)\end{array}$ & $7.4 \pm 0.1(6)$ & $6.9 \pm 0.1(8)$ & $8.0 \pm 0.1(8)$ & $8.3 \pm 0.1(8)$ \\
\hline Aspaminol & $\begin{array}{l}\left(\mathrm{pA}_{2}\right) \\
\left(\mathrm{pD}_{2}^{\prime}\right)\end{array}$ & $4.4 \pm 0.1(9)$ & $5.7=0.1(10)$ & $5.1 \pm 0.3(8)$ & $6.4 \pm 0.1(8)$ \\
\hline Papaverine & $\begin{array}{l}\left(\mathrm{pA}_{2}\right) \\
\left(\mathrm{pD}_{2}\right)\end{array}$ & $4.8 \pm 0.1(6)$ & $4.1 \pm 0.1(8)$ & $5.4 \pm 0.1(8)$ & $4.5 \pm 0.1(8)$ \\
\hline
\end{tabular}

Each value represents the mean $\pm S$.E. of the number of experiments in the parenthesis. 
artery, aorta and trachea in a noncompetitive manner. whereas it parallelly shifted the concentration-response curve for $\mathrm{CaCl}_{2}$ to the right in taenia coli. Potencies of the relaxants are presented in Table 1 as $\mathrm{pD}_{2}$ values in the cases in which the maximal responses were reduced or $\mathrm{pA}_{2}$ values in the cases in which the concentration-response curves were parallelly shifted to the right for convenience sake.

Influences of D 600, Aspaminol and papaverine on $\mathrm{KCl}$-induced contractions in isolated rabbit basilar artery, aorta, taenia coli and trachea (Fig. 2, Table 2): D 600 reduced maximal responses elicited by $\mathrm{KCl}$ in normal buffer solution in all of the tissues. The reduction was most remarkable in basilar artery. The reductions in basilar artery and aorta were not influenced by increasing concentration of $\mathrm{CaCl}_{2}$ in bathing fluids, whereas the reductions in taenia coli and trachea were significantly reversed by increasing the concentration of $\mathrm{CaCl}_{2}$ in bathing fluids. Aspaminol reduced maximal responses elicited by $\mathrm{KCl}$ in the same magnitude in all of the tissues. The reduction in basilar artery was not influenced by increasing the concentration of $\mathrm{CaCl}_{2}$ in

D 600
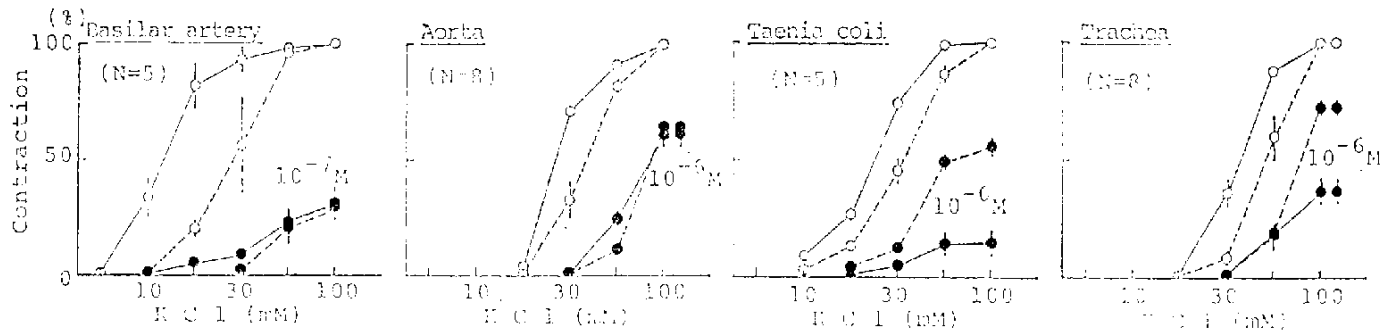

Aspaminol
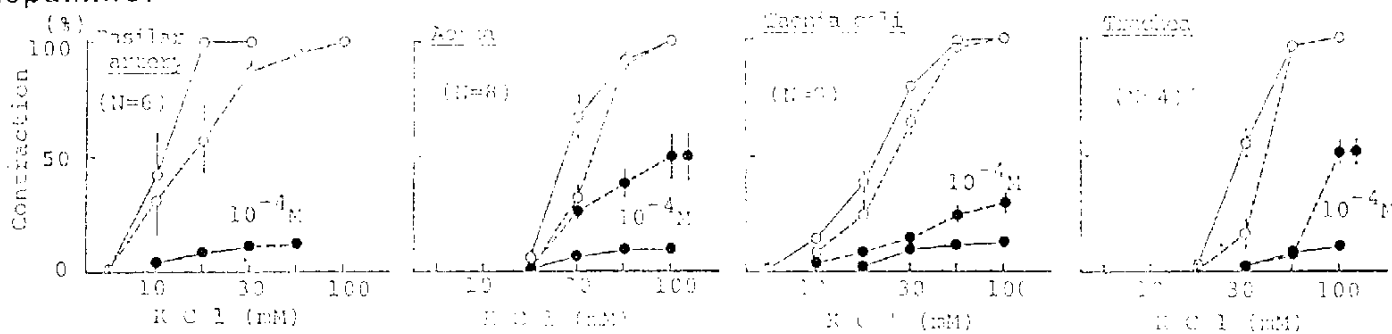

Papaverine
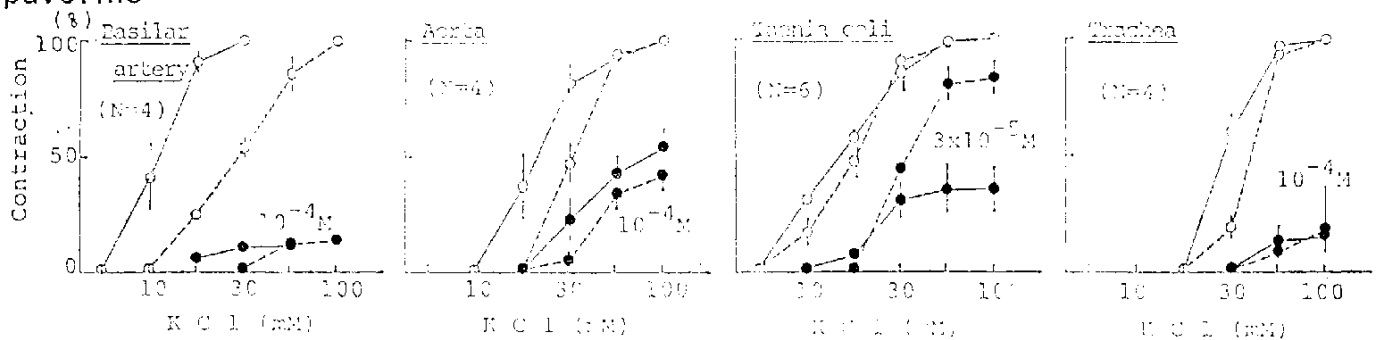

Fig. 2. Influence of increasing concentration of external $\mathrm{Ca}$ on the inhibitory actions of $\mathrm{D} 600$ (top), Aspaminol (middle) and papaverine (bottom) to isosmotic $\mathrm{KCl}$-induced contractions of isolated rabbit basilar artery, aorta, taenia coli and tracheal smooth muscle. The concentration of smooth muscle relaxant is shown in each figure. O: control. : treated. Solid lines indicate the results in normal buffer solution ( $\mathrm{Ca}: 2.5 \mathrm{mM}$ ), and dotted lines indicate the results in high $\mathrm{Ca}$ buffer solution ( $\mathrm{Ca}: 12.5 \mathrm{mM}$ ). Each point and vertical bar represent the mean value and standard error, respectively. N: Number of experiments. 
Table 2. Influence of increasing external Ca concentration on the noncompetitive antagonistic activities of D 600. Aspaminol and papaverine to isosmotic $\mathrm{KCl}$-induced contractions of isolated rabbit basilar artery, aorta, taenia coli and tracheal smooth muscle

\begin{tabular}{|c|c|c|c|c|c|}
\hline Drugs & & Basilar artery & Aorta & Taenia coli & Trachea \\
\hline \multirow{2}{*}{ D 600} & (Normal) & $7.4 \pm 0.2$ & $6.1 \pm 0.1$ & $6.4 \pm 0.1$ & $6.3 \pm 0.1 \quad$ (8) \\
\hline & (High $\mathrm{Ca}$ ) & $7.5 \pm 0.1$ & $5.8 \pm 0.1$ & $5.8 \pm 0.1^{* *}(5)$ & $5.6 \pm 0.1^{* *}(8)$ \\
\hline \multirow{2}{*}{ Aspaminol } & (Normal) & $4.9 \pm 0.1$ & $5.0 \pm 0.02(8)$ & $4.9 \pm 0.1 \quad$ (8) & $5.0 \pm 0.02$ \\
\hline & (thigh Ca) & $4.8 \pm 0.1 \quad(6)$ & $4.0 \pm 0.2 * *(8)$ & $4.4 \pm 0.1^{*}$ (8) & $4.0 \pm 0.1^{* *}(5)$ \\
\hline \multirow{2}{*}{ Papaverine } & (Normal) & $4.9 \pm 0.1 \quad$ (4) & $3.9 \pm 0.1$ & $4.5 \pm 0.1 \quad(6)$ & $4.7 \pm 0.2$ \\
\hline & (High $\mathrm{Ca}$ ) & $4.8 \pm 0.1 \quad$ (4) & $4.1 \pm 0.1$ & $3.7 \pm 0.2^{* *}(6)$ & $4.5 \pm 0.2$ \\
\hline
\end{tabular}

Antagonistic activities are represented by $\mathrm{pD}_{2}$ values. Each value represents the mean $=S$. E. of the number of experiments in the parenthesis. ${ }^{*},{ }^{* *}$ : Significantly different from the value in normal buffer solution ( $P<0.05, P<0.01$, respectively).

bathing fluid, whereas the reductions in aorta, taenia coli and trachea were significantly reversed by increasing the concentration of $\mathrm{CaCl}_{2}$ in bathing fluids. Papaverine also reduced maximal responses elicited by $\mathrm{KCl}$ in all of the tissues. The reductions in basilar artery, aorta and taenia coli were not influenced by increasing the concentration of $\mathrm{CaCl}_{2}$ in bathing fluids. whereas the reduction in taenia coli was significantly reversed by increasing the concentration of $\mathrm{CaCl}_{2}$ in bathing fluid.

Influences of D 600, Aspaminol and papaverine on histamine-induced contractions in isolated rabbit basilar artery, aorta and taenia coli (Figs. 3 and 4, Table 3): D 600 inhibited histamine-induced maximal responses of basilar artery, aorta and taenia coli in normal buffer solution. The order of potency of the inhibition was in taenia coli> basilar artery $>$ aorta. In aorta, D $600\left(10^{-5}\right.$ $10^{-4} \mathrm{M}$ ) shifted the concentration-response curve for histamine to the right with slight reduction of maximal response. The reductions of maximal responses in basilar artery and taenia coli were not reversed, but that in aorta was only slightly reversed by increasing concentration of $\mathrm{CaCl}_{2}$ in bathing fluids. Aspaminol reduced histamine-induced maximal contractions in basilar artery and taenia coli. In aorta. Aspaminol shifted the concentration-response curve for histamine to the right without reduction of maximal response. The reduction of the maximal response to histamine by Aspaminol was significantly reversed by increasing the concentration of $\mathrm{CaCl}_{2}$ in bathing fluid in taenia coli, but not in basilar artery. Papaverine reduced histamine-induced maximal responses of basilar artery, aorta and taenia coli in normal buffer solution. These reductions were not influenced by increasing the concentration of $\mathrm{CaCl}_{2}$ in bathing fluids. Figure 4 shows the influences of D 600. Aspaminol and papaverine on histamine-induced contractions of basilar artery, aorta and taenia coli in Ca-free buffer solution. Inhibitory activities of all the relaxants on histamineinduced contraction in Ca-free and normal buffer solution were almost the same as in basilar artery and aorta, but were not the same in taenia coli.

Tracheal smooth muscle did not contract in response histamine in $\mathrm{Ca}$-free as well as normal buffer solution.

\section{Discussion}

As mentioned above, the actions of smooth muscle relaxants are considered to vary with the differences of tissues, conditions during the development of contraction and other factors $(20,21)$. In this study, the effects of D 600 . Aspaminol and papaverine on contractile responses elicited 


\section{600}

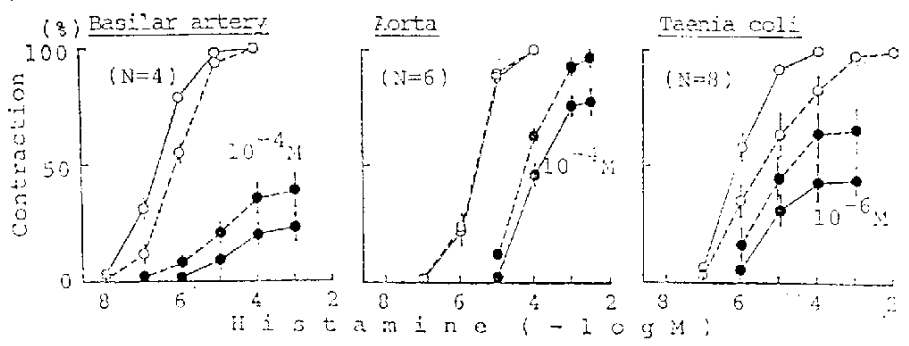

Aspaminol

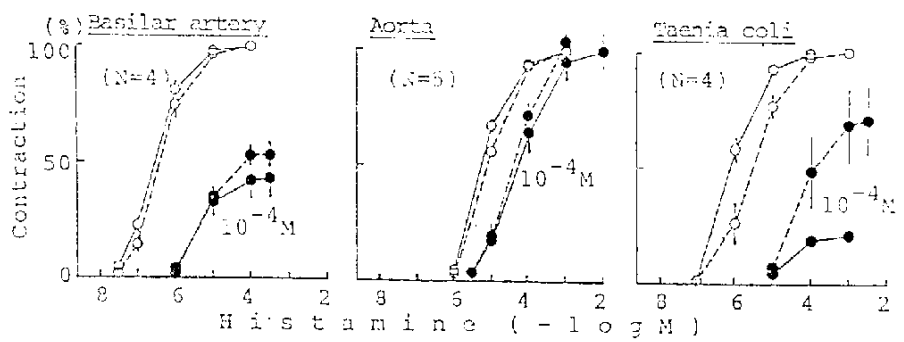

\section{Papaverine}

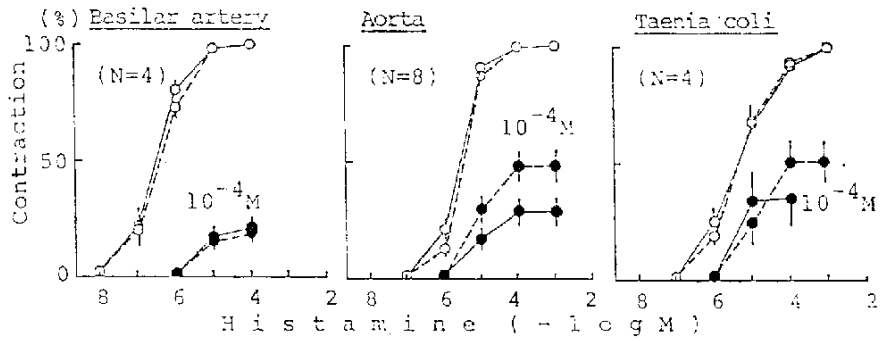

Fig. 3. Influence of increasing concentration of external $\mathrm{Ca}$ on the inhibitory actions of D 600 (top). Aspaminol (middle) and papaverine (bottom) to histamine-induced contractions of isolated rabbit basilar artery, aorta and taenia coli. The concentration of smooth muscle relaxant used is shown in each figure. $\mathrm{O}$ : control, O: treated. Solid lines indicate the results in normal buffer solution (Ca: $2.5 \mathrm{mM}$ ), and dotted lines indicate the results in high $\mathrm{Ca}$ buffer solution ( $\mathrm{Ca}: 12.5 \mathrm{mM}$ ). Each point and vertical bar represent the mean value and standard error, respectively. N: Number of experiments.

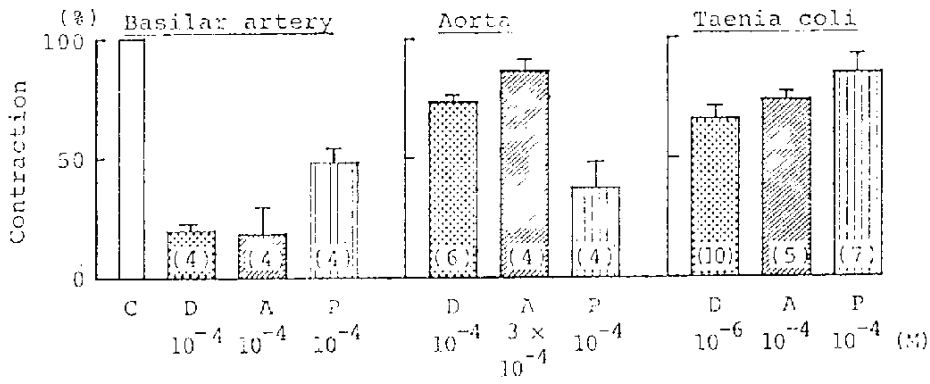

Fig. 4. Influences of $D 600$ (D). Aspaminol (A) and papaverine (P) on histamine $\left(10^{-4} \mathrm{M}\right)$-induced contractions of isolated rabbit basilar artery, aorta and taenia coli after the external $\mathrm{Ca}$ was removed. See "Methods" for details. Control responses (C) are considered as 100\%. Each value in parenthesis represents the number of experiments. Vertical bar represents the standard error. 
Table 3. Influence of increasing external Ca concentration on the antagonistic activities of D 600 . Aspaminol and papaverine to histamine-induced contractions of isolated rabbit basilar artery, aorta and taenia coli

\begin{tabular}{cllllll}
\hline \multirow{2}{*}{ Drugs } & & \multicolumn{2}{c}{ Basilar artery } & \multicolumn{2}{c}{ Aorta } & \multicolumn{1}{c}{ Taenia coli } \\
\multirow{2}{*}{ D 600} & (Normal) & $4.5 \pm 0.2$ & $(5)$ & $3.4 \pm 0.1$ & $(6)$ & $6.1 \pm 0.2(8)$ \\
& (High Ca) & $4.2 \pm 0.1$ & $(5)$ & $<3.08$ & $(6)$ & $5.8 \pm 0.2 \quad(8)$ \\
\hline \multirow{2}{*}{ Aspaminol } & (Normal) & $4.1 \pm 0.2$ & $(4)$ & $<2.58$ & $(4)$ & $4.6 \pm 0.04(5)$ \\
& (High Ca) & $3.9 \pm 0.1$ & $(4)$ & $<2.58$ & $(4)$ & $3.6 \pm 0.3^{* *}(5)$ \\
\hline \multirow{2}{*}{ Papaverine } & (Normal) & $4.6 \pm 0.2$ & $(5)$ & $4.4 \pm 0.1$ & $(8)$ & $4.3 \pm 0.3(5)$ \\
& (High Ca) & $4.7 \pm 0.1$ & $(5)$ & $4.1 \pm 0.1$ & $(8)$ & $4.0 \pm 0.2 \quad(5)$ \\
\hline
\end{tabular}

Antagonistic activities are represerited by $\mathrm{pD}_{2}$ values. Each value represents the mean \pm S.E. of the number of experiments in the parenthesis. **: Significantly different from the value in normal buffer solution $(P<0.01)$. \&: The concentration-response curves for histamine shifted to the right by $D 600$ and Aspaminol.

by $\mathrm{CaCl}_{2}$ in high- $\mathrm{K}$ depolarizing solution. $\mathrm{KCl}$ and histamine in both normal and high $\mathrm{Ca}$ buffer solution were compared with each other.

D 600, a $\mathrm{Ca}$ antagonist, inhibited $\mathrm{CaCl}_{2}$ induced contractile responses of the tissues used in this study. These results were confirmed by the experiments using $\mathrm{KCl}$ as an agonist in which $\mathrm{D} 600$ reduced $\mathrm{KCl}$ induced maximal responses in all of the tissues, and the reductions in taenia coli and trachea were significantly reversed by increasing external $\mathrm{CaCl}_{2}$ concentration, but those in basilar artery and aorta were not reversed. These results suggest that $D 600$ might block the influx of extracellular $\mathrm{Ca}$ competitively in taenia coli and trachea and noncompetitively in basilar artery and aorta at the voltage sensitive $\mathrm{Ca}$ channel which is activated by $\mathrm{KCl}$-induced membrane depolarization (7, 8). Schümann et al. (22) and van Breemen et al. (23) have reported similar findings that $\mathrm{Ca}$ antagonists such as nifedipine, diltiazem and others show noncompetitive antagonism against $\mathrm{CaCl}_{2}$ induced contractile responses in vascular tissues. Van Breemen et al. (23) have further described that diltiazem inhibits $\mathrm{Ca}$ influx by interacting with the Ca pathway involved in excitation rather than competing with $\mathrm{Ca}$ for the entry in rabbit aorta. D 600 inhibited histamine-induced contractile responses noncompetitively in basilar artery and taenia coli. These results also suggest that $D 600$ might block influx of extracellular Ca noncompetitively in these tissues at the $\mathrm{Ca}$ channel activated by histamine. The fact that $D 600$ parallelly shifted the concentration-response curve for histamine in aorta may have something in common with the observations described by Fairhurst et al. (24) and Karliner et al. (25) that D 600 and verapamil inhibit specific ligand binding to membrane receptors; this result may have to be explained by other experimental steps such as a binding assay for histamine receptors. Tracheal smooth muscle did not contract by histamine as reported by Fleisch et al. (26). Aspaminol inhibited $\mathrm{CaCl}_{2}$-induced contractions in a competitive manner in aorta, taenia coli and trachea and in a noncompetitive manner in basilar artery. The result in taenia coli was consistent to that reported by Takayanagi et al. (27). These manners of inhibition were confirmed by the experiments using $\mathrm{KCl}$ in both normal and high $\mathrm{Ca}$ buffer solutions. From these results, it was suggested that Aspaminol might block influx of extracellular Ca competitively in aorta, taenia coli and trachea and noncompetitively in basilar artery at the voltage sensitive $\mathrm{Ca}$ channel. Furthermore, the results of the experiments using 
histamine in both normal and high $\mathrm{Ca}$ buffer solution suggest that Aspaminol blocks influx of extracellular $\mathrm{Ca}$ competitively in taenia coli and noncompetitively in basilar artery. Aspaminol at a higher concentration $\left(3 \times 10^{-4} \mathrm{M}\right)$ shifted the concentrationresponse curve for histamine slightly to the right without reduction of the maximal response. This result also may have to be explained by other experimental steps. Papaverine, a nonspecific smooth muscle relaxant, inhibited $\mathrm{CaCl}_{2}$-induced contractile responses in a competitive manner in taenia coli and in a noncompetitive manner in other tissues. Although the result in taenia coli is interesting and consistent with that reported by some investigators $(28,29)$, it is considered that further studies are necessary to clarify the reasons why papaverine showed competitive (or apparently competitive) antagonism only in taenia coli among the tissues used in this study. These results with papaverine were confirmed by the experiments using $\mathrm{KCl}$ in both normal and high $\mathrm{Ca}$ buffer solutions. The results described above indicate that there is a variety of properties in the $\mathrm{Ca}$ channel activated by $\mathrm{KCl}$-induced membrane depolarization (so called voltage sensitive Ca channel) as well as that activated by histamine (possibly the so called receptor operated $\mathrm{Ca}$ channel) among different types of smooth muscle tissues. Moreover, it was indicated that the properties of the Ca channel activated by $\mathrm{KCl}$-induced membrane depolarization might differ from that activated by histamine in each tissue type.

In aorta, potencies of the inhibitory effect of smooth muscle relaxants used in this study on histamine-induced contractions in normal buffer solution were similar to those in $\mathrm{Ca}$ free buffer solution in which the contractions might be due to the release of $\mathrm{Ca}$ ions from an intracellular pool; while in taenia coli, there was no similarity, and inhibitory effects of relaxants in $\mathrm{Ca}$-free buffer solution were considerably smaller than those in normal buffer solution. Histamine is considered to cause not only membrane depolarization (12. 30-32), but also release of intracellularly sequestered $\mathrm{Ca}(12,33)$ in vascular smooth muscle, whereas it causes the contraction mainly due to the influx of extracellular $\mathrm{Ca}$ in taenia coli $(13,14,27)$. We have little information concerning agents which inhibit the release of intracellularly sequestered $\mathrm{Ca}$ in smooth muscles; however, the results in $\mathrm{Ca}$ free buffer solution suggest that the inhibitions of histamine-induced release of intracellularly sequestered Ca by D 600. Aspaminol and papaverine in basilar artery and those by D 600 and papaverine in aorta might more or less contribute to the inhibitory effects of these relaxants in normal buffer solution, whereas they might be mainly due to the inhibition of histamine-induced influx of extracellular $\mathrm{Ca}$ in taenia coli. In addition, it seems that there is also variety in the properties of the histamine-sensitive $\mathrm{Ca}$ store among the smooth muscle tissue types because the inhibitory effects of relaxants on the contractions in $\mathrm{Ca}$-free buffer solution varied with smooth muscle tissue types.

in conclusion, as well as the difference in dependence upon either an influx of extracellular $\mathrm{Ca}$ or a release of intracellularly sequestered $\mathrm{Ca}$, the properties of $\mathrm{Ca}$ influx pathways ( $\mathrm{Ca}$ channels) and cellular $\mathrm{Ca}$ stores seem to vary in a complex manner with the difference in tissue types and/or contracting agents. These might be attributable to the various actions of smooth muscle relaxants in various tissue types; and furthermore. it may become necessary to have further subclassifications of $\mathrm{Ca}$ channels and Ca stores.

\section{References}

1) Filo, R.S., Bohr, D.F. and Rüegg, J.C.: Glycerinated skeletal and smooth muscle: Calcium and magnesium dependence. Science 147, 1581$1583(1965)$ 
2) Somlyo, A.P. and Somlyo, A.V.: Vascular smooth muscle. 1. Normal structure, pathology. biachemistry and biaphysics. Pharmacol. Rev. 20, 197-272 (1968)

3) Somlyo, A.V. and Somlyo, A.P.: Strontium accumulation by sarcoplasmic reticulum and mitochondria in vascular smooth muscle. Science 174, 955-958 (1971)

4) Vallieres, J., Scarpa, A. and Somlyo, A.P.: Subcellular fractions of smooth muscle. Isolation, substrate utilization and $\mathrm{Ca}^{2+}$ transport by main pulmonary artery and mesenteric vein mitochondria. Arch. Biochem. Biophys. 170, 659-669 (1975)

5) Deth, R. and Casteels, R.: A study of releasable Ca fractions in smooth muscle cells of the rabbit aorta. J. Gen. Physiol. 69, 401-416 (1977)

6) Fleckenstein, A., Tritthart, H., Fleckenstein, B., Herbst, A. and Grün, G.: A new group of competitive $\mathrm{Ca}$-antagonists (Iproveratril, D 600. Prenylamine) with highly potent inhibitory effects on excitation-contraction coupling in mammalian myocardium. Pfluegers. Arch. 307, R25 (1969)

7) Su, C. and Bevan, J.A.: The electrical response of pulmonary artery muscle to acetylcholine. histamine and serotonin. Life Sci. 4, 1025-1029 (1965)

8) Bolton, T.B.: Mechanism of action of transmitters and other substances on smooth muscle. Physiol. Rev. 59, 606-718 (1979)

9) Flaim, S.F. and Zelis, R.: Clinical use of calcium entry blockers. Fed. Proc. 40, 28772881 (1981)

10) Vanhoutte, P.M.: Calcium entry blockers and cardiovascular failure. Fed. Proc. 40, 28822887 (1981)

11) Goodman, F.R.: Calcium-channel blockers and respiratory smooth muscle. In New Perspectives on Calcium Antagonists, Edited by Weiss, G.B., p. 217-222. American Physiological Society. Bethesda (1981)

12) Hudgins, P.M. and Weiss, G.B.: Differential effects of calcium removal upon vascular smooth muscle contraction induced by norepinephrine. histamine and potassium. J. Pharmacol. Exp. Ther. 159, 91-97 (1968)

13) Takayanagi, I., Hongo, T. and Kasuya, Y.: Difference in the mechanisms by which acetylcholine and histamine interact with $\mathrm{Ca}^{2+}$ to contract the rabbit taenia coli. J. Pharm. Pharmacol. 29, 775-776 (1977)

14) Takayanagi, 1., Hongo, T., Hisayama, T. and Kasuya, Y.: Effects of acetylcholine and histamine on mechanical activity of rabbit taenia coli, Ca-incorporation and Ca-release in its microsomal fraction. J. Pharmacobiodyn. 2, 212-218 (1979)

15) Farley, J.M. and Miles, P.R.: The sources of calcium for acetylcholine-induced contractions of dog tracheal smooth muscle. J. Pharmacol. Exp. Ther. 207, 340-346 (1978)

16) Casteels, R. and Raeymaekers, L.: The action of acetylcholine and catecholamines on an intracelluiar calcium store in the smooth muscle cells of the guinea-pig taenia coli. J. Physiol. (Lond.) 294, 51-68 (1979)

17) Brading, A.F. and Sneddon, P.: Evidence for multiple sources of calcium for activation of the contractile mechanism of guinea-pig taenia coli on stimulation with carbachol. Br. J. Pharmacol. 70, 229-240 (1980)

18) Bohr, D.F.: Vascular smooth muscle updated. Circ. Res. 32, 665-672 (1973)

19) Casteels, R. and Droogmans, G.: Evidence for a direct pathway between the noradrenaline sensitive calcium store and extracellular space. J. Physiol. (Lond.) 313, 32P (1981)

20) Van Nueten, J.M. and Vanhoutte, P.M.: Calcium entry blockers and vascular smooth muscle heterogeneity. Fed. Proc. 40, 28622865 (1981)

21) Godfraind, T.: Mechanisms of action of calcium entry blockers. Fed. Proc. 40, 2866-2871 (1981)

22) Schümann, H.J., Görlitz, B.D. and Wagner, J.: Influence of papaverine, D 600 , and nifedipine on the effects of noradrenaline and calcium on the isolated aorta and mesenteric artery of the rabbit. Naunyn Schmiedebergs Arch. Pharmacol. 289, 409-418 (1975)

23) Van Breemen, C., Hwang, $O$. and Meisheri, K.D.: The mechanism of inhibitory action of diltiazem on vascular smooth muscle contractility. J. Pharmacol. Exp. Ther. 218, 459$463(1981)$

24) Fairhurst, A.S., Whittaker, M.L. and Ehiert, F.J.: Interactions of D 600 (methoxyverapamil) and local anesthetics with rat brain $\alpha$-adrenergic and muscarinic receptors. Biochem. Pharmacol. 29, 155-162 (1980)

25) Karliner, J.S., Motulsky, H.J., Dunlap, J., Brown, J.H. and Insel, P.A.: Verapamil competitively inhibits $\alpha_{1}$-adrenergic and muscarinic but not $\beta$-adrenergic receptors in rat myocardium. J. Cardiovasc. Pharmacol. 4, 515-520 (1982)

26) Fleisch, J.H. and Calkins, P.J.: Comparison of drug-induced responses of rabbit trachea and bronchus. J. Appl. Physiol. 41, 62-66 (1976)

27) Takayanagi, I., Hisayama, T., Yoshida, Y. and Koike, K.: Effects of nonspecific smooth muscle 
relaxants on calcium-uptake by microsomal fraction and their inhibitory action in rabbit taenia coli. J. Pharmacobiodyn. 3, 160-166 (1980)

28) Ferrari, $M_{\text {.: }}$ Interactions between calcium and some myolytic agents on depolarized vascular smooth muscle. J. Pharm. Pharmacol. 22, 71-72 (1970)

29) Simonis, A.M., Ariëns, E.J. and van den Broeke, J.J.W.: Non-competitive spasmolytics as antagonist of $\mathrm{Ca}^{++}$-induced smooth muscle contraction. J. Pharm. Pharmacol. 23, 107-110 (1971)

30) Cuthbert, A.W. and Sutter, M.C.: The effects of drugs on the relation between the action potential discharge and tension in a mammalian vein. Br. J. Pharmacol. 25, 592-601 (1965)

31) Somlyo, A.V. and Somlyo, A.P.: Electromechanical and pharmacomechanical coupling in vascular smooth muscle. J. Pharmacol. Exp. Ther. 159, 129-145 (1968)

32) Harder, D.R.: Membrane electrical effects of histamine on vascular smooth muscle of canine coronary artery. Circ. Res. 46, 372-377 (1980)

33) Goodman, F.R. and Weiss, G.B.: Effects of lanthanum on ${ }^{45} \mathrm{Ca}$ movements and on contractions induced by norepinephrine, histamine and potassium in vascular smooth muscle. J. Pharmacol. Exp. Ther. 177, 415-425 (1971) 